\title{
Review of Accounting Gimmicks Called Depreciation
}

\author{
Onojah Attah Lawrence ${ }^{1}$, Unegbu Angus Okechukwu² \\ ${ }^{1}$ Department Accountancy, University of Maiduguri, Maiduguri, Nigeria \\ ${ }^{2}$ School of Business and Entrepreneurship, American University of Nigeria, Yola, Nigeria \\ Email: unegbu4@yahoo.com
}

Received January 10, 2013; revised March 12, 2013; accepted March 30, 2013

Copyright ( 2013 Onojah Attah Lawrence, Unegbu Angus Okechukwu. This is an open access article distributed under the Creative Commons Attribution License, which permits unrestricted use, distribution, and reproduction in any medium, provided the original work is properly cited.

\begin{abstract}
Depreciation is a complex, intricate and confusing term in the fields of engineering, social and management sciences. As a result, it has been over used, over stressed, and over worked by the accountants and professional valuers. International Accounting Standard (IAS) 4, qualifies assets for depreciation when assets are used for more than one accounting period, i.e. assets held by an enterprise for production or service, and has economic useful life. Whereas, under Standard Statement of Accounting Practice (SSAP) 12, depreciation is viewed as wearing out, consumption or other loss of value of fixed asset, whether arising from use, affluxion of time or obsolescence through technology and market changes. Complexity may arise when it is viewed as a fall in price, physical deterioration, allocation of cost, fall in value, valuation technique and asset replacement. Intricate and confusion are inevitable when accountants employ various methods of providing for depreciation on the same or similar assets of different life span. These methods may include straight line, reducing balance, sum of the year's digit, revaluation, annuity, output, sinking fund etc which will definitely give different values in the financial statement. The consequential effect is either to undermine or overstate the reported profit or distributable profit in the hands of the stakeholders, hence the absurdity of the financial reports. It is recommended that depreciation should be used with caution especially when the anticipated economic useful lives of the asset is short lived by new technology or passage of time thereby making it extremely difficult to recover or replace the net book value of the asset.
\end{abstract}

Keywords: Depreciation; Measuring Profitability; Expense Capture; Corporate Performance Measures; Earnings Engineering

\section{Introduction}

Currently the theory and practice of depreciation have not generally unified the fixed amount to be charged as annual expenses in the Income Statement and Balance Sheet due to different meanings and computations. Although materiality concept affirms that what might be material to one person/company may not necessarily be material to another person/company (Concept of Value). Materiality concept is viewed as fundamental when inclusion, exclusion of a particular item, transaction into or from the financial statement could lead to distortion, misleading and/or debase financial statement anticipated report, meaning and understanding. In order to avoid this confusing nature of any inclusion or exclusion there is the need to explain vividly such aspects in the form of notes to the accounts which gives credence and reliability to the users of financial statement.

The word depreciation has been grossly over worked, over used, over stressed and above all has varying senses with different connotations even among intra and inter group disciplines. International Accounting Standard (IAS) 4 and Statement of Standard Accounting Practice (SSAP) 12 view standards in accounting for depreciation as the allocation of depreciable amount of assets over its estimated useful life. Depreciable amount from assets is anchored on its historical cost in the financial statements less estimated residual value. IAS 4 stresses that depreciable amount of an asset includes:

1) Assets used for more than one accounting period.

2) Assets that have initial useful life.

3) Assets held for use or for supply of goods and services or for rental or for administrative purposes.

SSAP 12, views accounting for depreciation as the measure of the wearing out, consumption or other loss of value of fixed asset, whether arising from use, affluxion of time or obsolescence through technology and market 
changes.

Analysis of IAS 4 and SSAP 12 may differ in content and form and could be reconciled under a high technical accounting surgery. The vagueness of depreciation in accounting literature, a concern to accountants includes:

1) As a fall in price, 2) As a physical deterioration, 3) As a fall in value, 4) As an allocation of cost, 5) As asset replacement, 6) As a valuation technique.

The IAS 4, SSAP 12 and other accounting literature remain a source of reference in the methods, choice, and reporting of depreciation in the financial statements. NASB, IASC, ASSC etc are charged with the responsibilities of formulating accounting standards and are yet to come up with contrary opinion on how to:

1) Examine the scope and application of depreciation under IAS4 and SSAP12 and its effects on financial reporting.

2) Assess the economic value of depreciation in enterprise.

3) Examine the continuous relevance of depreciation in an inflationary economy.

\subsection{Objective of the Study}

The main objective of this paper is to review the various methods and factors necessary for providing for annual depreciation in financial reporting and assess the economic benefits of providing for depreciation.

They specific objectives are to:

- identify the effects of theoretical and practical approaches in providing for depreciation on financial reports using the available methods under IAS 4 and SSAP 12;

- identify the unification of materiality concept that would not undermine the profit figure in the financial statement;

- examine some pecuniary abuses of providing for depreciation based on different meanings, applications and computation of historical cost value of business assets.

\subsection{Justification for the Review}

The bodies charged with the responsibilities to formulate, publish, Implement and establish accounting standards include: Nigeria Accounting Standard Board (NASB), International Accounting Standard Committee (IASC), and Accounting Standard Steering Committee (ASSC), etc and would no doubt integrate the various ideological thought into a general framework of reference in reporting depreciation in the financial statements. This will create awareness and harmonizes the consequences of choice of depreciation among firms in their methods of providing for depreciation. It will reduce the trickery nature of reporting high depreciation value in a bid for assets replacement which may erode both profits and assets values at the balance sheet dates.

Finally, this approach will inject new accounting techniques and eliminate depreciation fibroid for true and fair view in financial reporting.

\section{Review of the Accounting Concept of Depreciation}

International Accounting Standard 8 (Accounting Policies, Changes in Accounting Estimates and Errors) made overwhelming assertions on the conceptualization of depreciation and method of presentation in the financial statements. The assertions of IAS 8 notwithstanding, many Accountants are yet to decide whether Depreciation should be conceived as accounting policy or as accounting estimates. Each of these conceptions has a different effect on the Entities' performance presentation. This section of the paper will focus on reviewing the purpose, methods and different profession's conception of depreciation.

\subsection{State of the Art: An Overview of Depreciation}

It is observed by [1,2] that the purpose of depreciation is to allocate a fair proportion of the cost of fixed asset over assets' useful life. SSAP12 requires that provision for the depreciation of fixed asset with finite useful lives as should be made as thus:

1) Allocate cost or revalued amount less estimated residual value as fairly as possible over the number of years expected to benefit from the use of the asset.

2) Replacement of fixed assets at the end of their useful life by making depreciation charge. Funds, which might otherwise be distributed as dividend could be retained within the organization. This standard does not regard adequacy of funds as a criteria for assets replacement.

3) As a revaluation technique. The theoretical belief, in decrease in the economic value of an asset may not be correct in practice as it has little or no relationship in valuation technique. The word inflationary trend has justified the fact that depreciation has little in common with measurement of value.

4) As a measure of physical deterioration. Depreciation is much more than ordinary physical deterioration. The physical factors are not only parts of the element as the economy and obsolescence are taking into consideration in calculating the depreciation, but also time and changes in technology.

5) As a fall in price and replacement of asset at the end of its economic useful life. Incorrect deductions on the written down value does not amount to fall in price of the asset at the period of replacement. More so, the accumu- 
lated written down value hardly replaces the asset especially at the time of galloping inflation. Depreciation as the allocation of net historical cost of an asset may meet the current thinking in accounting.

6) Finally as a reward for asset employed in the production of goods and services. Just like reward to factors of production (land, labour, capital and entrepreneur) in the form of rent, wages, interest and profit respectively.

\subsection{Some Conventional Unresolved Issues about Depreciation}

The long standing confusion about depreciation in accounting practice appears to be the lack of agreement among accountants on what the word depreciation means. It is suggested by $[3,4]$ that though depreciation is a decline in price of any asset, it is derived from Latin, "de" meaning from and "pretium" meaning price. Conventional accounting practice in respect to depreciable assets, depreciation means reducing the purchasing price to the ultimate selling price at the point of disposal. Reference is usually made to the market value only at the beginning and at the end of the lifetime of an asset. These assertions also got the support of [5]. However, [6,7] viewed depreciation as physical deterioration of asset. Others view it as deferred maintenance. Depreciation is defined by [8], citing United States Supreme Court, in the case of Lindheimer V lllinois Bell Telephone Co. 292, US 151, (1934), as a loss not restored by current maintenance which is due to all factors causing the ultimate retirement of the property.

Accountants are concerned with the financial aspect and not the physical factors. Other professionals such as Engineering have their own depreciation concepts. It is attributed by [9] that physical factors to an engineering problem in which depreciation has special meaning relates to wear and tear of productive plants and equipment. This concept is supported by [10] as he stated that depreciation is a diminution of value by reason of wears and tears, physical deterioration of assets may not be caused by using them in production but by other factors such as decay, rust, corrosion and technological changes. In his writing, [11] outlined Economists concept of value, which is cost value, exchange value, used or utility and esteem value of relative importance is faced with considerable difficulty in understanding the concept. Unless the value of asset is specified, economic value is not relevant to the measurement of depreciation. It is viewed as a provision for the replacement of durable asset (worn-out) at the end of its useful life.

Four possibilities of assets replacement are distinguished by [12], thereby giving support to earlier view of [8] as: replacement of subjective value, replacement of original cost, physical replacement at the end of its useful life and the replacement in some form of market value. Depreciation is viewed as problem of allocation of original cost to match with current revenue by [13] but described by [14] as part of the fixed assets which is not recoverable when asset is finally put out of use. The provision against this loss of capital is an integral cost of conducting the business during the effective commercial life of the asset and is not dependent upon the amount of profit earned. However, there is considerable confusion about the nature and significance of the concept of depreciation in current accounting thought.

The traditional concept of depreciation is seen as a loss suffered by physical deterioration, a loss due to external causes to asset physical form, a provision for replacement, diminution in value, a process of cost allocation etc. It is glaring to note that none of these traditional concepts can provide a satisfactory interpretation to what accountants do in recording depreciation.

\subsection{Factors to Be Considered in Making Choice of Depreciation}

Certainly, if the traditional concept of depreciation must be adhered to, the need for objective criteria in determining depreciation value is called to question. For an asset to qualify for depreciation it may be influenced by the under mentioned properties as opined by [14]:

1) Historical cost of the asset. [12] citing the assertions of Exposure Draft (ED) 37, IAS 4, and SSAP 12, suggests that fixed asset can only be depreciated on the bases of its original cost. In determining the historical cost, other cost that is direct to the acquisition of the machine is added up to the purchase price, like agreement cost, installation cost, improvement cost, etc. This however will provide more objective criteria in allocating past costs to current revenue.

2) Similar to the historical cost, is the asset that must have an economic life span. Business as a going concern, unlike in the public sector where the whole cost of the asset is charged in the accounting period in which it was purchased. The productive effort of the asset in the private sector is spread over its commercial value. Professional Valuer is expected to estimate the economic useful life of the asset which will assist accountants in the choice of depreciation provision.

3) Salvage value is paramount in determining the value of depreciation. It is however necessary to recall that some assets may not have residual value at the end of its useful life. In other words it is said to be worthless, as a result of decay, corrosion etc.

4) Nature and type of assets. Obviously, the methods of providing for depreciation vary from one asset to another even in the same organization. Some equipment can be fragile or delicate to handle and the estimated life 
span is dependent on the asset maintenance. Similarly natural disaster could render assets economic life span useless, even though those assets have different monetary value, life span, and salvage value, etc.

5) Asset usage or capacity. Frequency and volume of production is highly necessary in making choice of deprecation. Some equipment can withstand the stress of continuity in the production process while others may not. Accordingly, capacity or volume of production may vary from one machine to another as some provision for depreciation is made on the basis of volume or capacity.

6) Improvement and development cost. It is similar to direct costs associated with the purchase price of the equipment to the existing asset resulting to assets efficiency, improvement in capacity, extension of economic life span etc.

\subsection{Methods of Providing for Depreciation}

In his work [15] citing IAS 4 and SSAP 12, recommend the under mentioned methods of depreciation of fixed assets which depend on the nature, type, life span, salvage value and historical cost of asset:

\section{1) Straight Line Method}

Apart from easy to understand and mathematical simplicity it lacks accounting justification as fixed annual charge is credited to asset account throughout its economic useful life. It believed by [16] that the strength, performance and repairs of the asset is constant, hence the annual fixed charge. This assumption opined by [17] is of course incorrect, as the asset is ageing, the strength and performance declines geometrically and maintenance and repair costs increases exponentially. Annual depreciation charge is the historical cost divided by the number of years of the asset less scrap value, as shown below:

$$
\mathrm{AD}=\frac{\mathrm{C}-\mathrm{R}}{\mathrm{N}}
$$

where $\mathrm{AD}=$ Annual depreciation charge.

$\mathrm{R}=$ Residual value, and $\mathrm{N}$-years of the asset.

$\mathrm{C}=$ Historical cost.

2) Accelerated Methods. It includes:

a) Reducing/Diminishing/Declining Balance Method: It is asserted by [18] that depreciation charge is obtained by applying a fixed percentage to the diminishing book value of the asset. Asset net book value is its cost less accumulated depreciation to date. It assumes that operational performance, strength and repairs are not constant as asset is aging. Hence arbitrariness cannot be over ruled. The general formula under this method is shown below:

$\mathrm{R}=\mathrm{C}(\mathrm{I}-\mathrm{D})^{\mathrm{n}}$ where $\mathrm{R}=$ residual value; $\mathrm{C}=$ historical cost; $\mathrm{n}=$ usage life of assets $\mathrm{D}$-depreciation rate in \%.
Alternatively: $\mathrm{r}=1-\mathrm{n} \sqrt{\frac{R}{C}}$ where $\mathrm{r}=$ depreciation rate in \%, $\mathrm{n}=$ useful life, $\mathrm{R}=$ scrap value; $\mathrm{C}=$ historical cost.

\section{b) The Sum of the Year's Digit Method}

It is a means of obtaining depreciation charges that are substantially higher in the early years and lower in the latter years. As in the USA it does so by applying constant diminishing rates to a constant depreciable amount by means of fractionalization, this is the assumption of [19]. This tends to be more popular as it recognizes that new asset has less repairs, maintenance cost, increase productivity and efficiency at the beginning of the period and less depreciation charges as the asset ages due to increase in repairs and maintenance costs that. The annual depreciation is equal to the rate multiplied by depreciation base i.e. cost of the asset. The quantitative expression of sum of the year's digit method that would aid understanding business operation is given in Table 1.

Supporting the assertions of [19], [16] is of the view that this approach signifies that as the assets is aging less depreciation charges will complement with the increase in repairs and maintenance cost during the financial year.

\section{c) Revaluation Method}

Writing about Revaluation method of depreciation, [18] opined that peculiarity, nature and type of asset may not permit an informed judgment to apply either straight line or accelerated methods. When the amount or physical deterioration is uncertain and difficult to ascertain, and coupled with improper valuation, may result to arbitrariness like live stock depreciation. Others may include farmer's tools, engineering tools, and contractor's equipment but [20] had it that this method becomes apparent when obsolescence, passage of time and changes in technology are the significant depreciation factors.

d) Output or Usage or Unit of Production Method Both $[12,15]$ had that this method allows apportionment of cost of fixed assets in relation to the output or usage each year. It tends to be more realistic where the output or usage varies significantly from one year to another due to machine breakdown, strikes, stock out of raw materials shot down of production. It ignores residual value of the assets; and expressed as: Annual dep.

Table 1. Accounting application of sum of the year's digit method.

\begin{tabular}{cccc}
\hline Yr. & Digit & Rate & Dep. Base Base (N’000) \\
\hline 1 & 1 & $4 / 10$ & 30 \\
2 & 2 & $3 / 10$ & 30 \\
3 & 3 & $2 / 10$ & 30 \\
4 & 4 & $1 / 10$ & 30 \\
\hline
\end{tabular}


Annual dep.(AD)

$$
=\frac{\text { Annual Output/Hours }}{\text { Total life/output/mach. Hr. }} \times \frac{\text { Cost of the assets }}{1}
$$

\section{e) Annuity or Rising Charges Method}

Usually, the capital locked up in the asset is regarded as earning interest; a constant annual charge for depreciation is credited to the asset account during the useful life of the assets, less scrap value, if any. It is the view of [3] that the interest earned be debited to the asset account, at a fixed percentage rate, but on reducing balance. This occurs when obsolescence supervenes the actual depreciation thereby shortening the estimated life of the asset. However, [11] maintained that this method suitable to long leases where incessant additions are made during its life. Actuarially, the cost of the asset is regarded as providing an annuity during its life, the value of annuity being the annual charge to depreciation. Usually, depreciation charged to profit and loss account is the difference between the notional interest and notational periodic rate of annuity whose present value is equal to 1 and is given as:

$$
P=\frac{i}{1-(1+i)^{-n}}
$$

where $i=$ annual interest rate in $\% ; n=$ number of years of the assets where the annual notional depreciation is given as

$$
\frac{c(i)}{1(1+i)^{-n}}
$$

where $C=$ historical cost $c(i)=$ notional interest.

It is possible to determine the annual depreciation, no- tional interest, and depreciation, using a lease which cost N6000 for 7 yrs term by an annuity of $61 / 2 \%$ interest charge per. Annum, as in Table 2.

It is disheartening to note that, as the asset becomes weak in operational performance with an increase repairs and maintenance cost at ageing period, the depreciation charges increase astronomically, [4,7] both agreed. The reported profit at this later age must have been drawn to abyss; thereby eroding the distributable profit in the hands of the stakeholder, hence distributable profit becomes un-distributable.

\section{f) Sinking Fund Method}

This method arranges for funds to be available for the replacement of assets at the end of its useful life [9]. The method involves the investment of cash outside the business. In addition, the aim is to make regular investment of money which together with the accumulated interest or dividend, is sufficient to finance replaceable assets by the firm. Even though the exact amount may be realized some factors militating against this noble objective as listed by [15] are:

- Change in science and technology may put off the assets out of use before end time.

- Change in price of the assets even though they may be of the same type, size, and capacity.

- The assets may have longer or shorter life span than the one to be replaced.

- Changes in the taxation system may affect the dividend or interest received or amount received on investments.

- The market value of investment may rise or fall due to inflation of which the realized value may differ considerably from the expected value when the

\begin{tabular}{|c|c|c|c|c|c|}
\hline Yr. & Bal. B/F & $\begin{array}{l}\text { Notional interest at } \\
\quad(612 \% c(i))\end{array}$ & $\begin{array}{l}\text { Notional depreciation } \\
\qquad \frac{c(i)}{1-(1+c)^{-n}}\end{array}$ & $\begin{array}{c}\text { Balance } \mathrm{C} / \mathrm{F} \\
C-\left[\frac{c(i)}{1-(1+c)^{-n}}-c(i)\right]\end{array}$ & $\begin{array}{l}\text { Annual dep. } \\
\frac{c(i)}{1-(1+c)^{-2}}-c(i)\end{array}$ \\
\hline & & $\mathrm{N}$ & $\mathrm{N}$ & $\mathrm{N}$ & $\mathrm{N}$ \\
\hline 1 & 6000 & 390 & 1094 & 5296 & 704 \\
\hline 2 & 5296 & 344 & 1094 & 4546 & 750 \\
\hline 3 & 4546 & 295 & 1094 & 3747 & 799 \\
\hline 4 & 3747 & 244 & 1094 & 2891 & 850 \\
\hline 5 & 2897 & 188 & 1094 & 1991 & 909 \\
\hline 6 & 1991 & 129 & 1094 & 1026 & 965 \\
\hline \multirow[t]{2}{*}{7} & 1026 & 68 & 1094 & 0 & 1026 \\
\hline & & & & & 6000 \\
\hline
\end{tabular}
scheme was first drawn.

Table 2. Rising charges method of providing for depreciation. 


\section{Conclusions and Recommendations}

The enigma of depreciation and depreciable assets and its application in financial reporting, exacerbate the current thinking in accounting practice. Because it lacks exactitude in methods, determination, and assessment, tax authority disallows depreciation as an allowable expense, and replaces it with capital allowance. Other reason postulated by tax authorities for disallowing depreciation expense is that it is not reasonably arrived at. Many others argue that depreciation expense included in financial statements is more of subjective decision. Parties to the financial statements may be overwhelmed or distressed because of the high or low reported profits which must have been influenced by the methods and rate of depreciation. The blanket, financial statements or window dressing financial report may not be the truth and fairness of the profit and loss account and the balance sheet.

The assumption, that depreciation is a valuation technique and assets replacement in business is incorrect. The inflationary trend has actually proved the above assumption incorrect. The price of assets yesterday changes astronomically that the accumulated depreciation cannot replace its value in today's or tomorrow's market.

Accountants are not unaware of the gross abuse, over worked, over-stressed, and over-used term, "depreciation”, in financial reporting and its divergent applications do result to conflicts of interest among users of financial statements. Nevertheless, its objective and application has come to stand as no counter tenets or rules have been formulated by the board charged with this responsibility.

It is as a fallout of this review that depreciation should be used with caution, especially when the anticipated economic useful lives of the asset is short-lived by new technology or passage of time, thereby making it extremely difficult to recover or replace the net book value of the Asset. It is also recommended that a persistent and constant policy be adopted in the choice of depreciation method so that the Firm's performances overtime can be objectively analyzed and positioned.

It is also recommended out of this review that enabling statues and standards be put in place, making it legally actionable in the use of depreciation as method of earnings engineering and falsification of financial statements. This will not only ensure consistency in the use of depreciation method but will also remove the subjective perception of deprecation outside accounting cycles. A stipulation of compressive accounting standard enforcing depreciation methods and circumstances for adoption will not only generate objective depreciation expense but will enhance its general acceptance and diminish its gimmicks perception among professionals.

\section{REFERENCES}

[1] O. Benjamine, "Studies in Accountancy-Text and Readings,” New-Age Publishers, Enugu, 1992, pp. 46-59.

[2] L. Goldberg, "Concept of Depreciation in MPB Perera," Accounting Theory, 1962, pp. 98-106.

[3] F. Wood, "Business Accounting 2,” 3rd Edition, Richard Clay Ltd., London, 2007, pp. 90-220.

[4] J. A. Akanni, "Management: Concepts, Techniques, and Cases,” Julab Publishers Limited, Ibadan, 1988, pp. 67-96.

[5] P. A. Samuelson, "Economics, International Students Edition,” McGraw-Hill Kogakusha Ltd., Auckland, 1979, pp. 134-148.

[6] J. C. Bonbright, "The Valuation of Property, in MPB Perera, Accounting Theory and Development,” Thomson Publishing Company, 1973, pp. 508-521.

[7] P. Gee, "Book Keeping and Accounts," Butter North Green Ltd., London, 1986, p. 37.

[8] M. R. Mathews and M. H. B. Perera, "Accounting Theory and Development,” Thomson Publishing Company, 1996, pp. 103-156.

[9] P. H. Turpin, et al., "Financial Accounting Advanced Techniques,” 2nd Edition, Financial Training Publication Ltd., London, 1986, pp. 320-347.

[10] E. Matheson, "Depreciation of Factories, Mines and Industrial Undertaking and Their Valuation,” Publishing Company, Parera, 1984, pp. 220-267.

[11] A. R. Anao, “An Introduction to Financial Accounting," Longman Nigeria Ltd., Benin City, 1996, pp. 206-257.

[12] A. R. Jennings, “Financial Accounting,” DP Publication Ltd., London, 1990, pp. 340-373.

[13] E. Omolehinwa, "Foundation of Accounting," Pumark Nigeria Ltd., Ikeja, 2003, pp. 107-185.

[14] Institute of Chartered Accountant in England and Wales, "Recommendations on Accounting Principle" Depreciation of Financial Assets, London, 1945, p. 73.

[15] L. O. Adekunle, “Accounting for Special Business,” Bayus Consults, Lagos, 2000, pp. 98-114.

[16] R. O. Igben, “Financial Accounting Made Simple,” ROI Publishers, Lagos, 1999, pp. 87-116.

[17] A. E. Okoye “Cost Accountancy-Management Operational Applications,” United City Press, Benin, 1997, pp. 79-106.

[18] E. O. Edwards, "Depreciation and Maintenance of Real Capital,” Thomson Publishing Company, Peera, 1961, pp. 432-476.

[19] McWell, "A Note on the Amortization of fixed Assets," The Accounting Review, 1968, pp. 556-589.

[20] R. Moody, "Principles of Accounts,” Hulton Educational Publications Ltd., 1974, pp. 136-145. 